\title{
PELUANG PENDIRIAN INDUSTRI SEMEN SEKALA KECIL DI KEPULAUAN MALUKU DAN WILAYAH PAPUA
}

\author{
Oleh : \\ Teuku Ishlah \\ Perekayasa Madya Bidang Program dan Kerja Sama - Pusat Sumber Daya Geologi
}

SARI

Indonesia memiliki potensi bahan baku semen seperti batu gamping, lempung, pasir kuarsa dan pasir besi yang tersebar diseluruh pulau-pulau besar dan pulau-pulau kecil. Namun untuk wilayah Kepulauan Maluku dan Papua, kebutuhan semen dipasok dari Sulawesi Selatan sehingga di daerah tersebut sering terjadi kelangkaan pasokan semen. Dilain pihak di beberapa negara, membangun pabrik semen sekala kecil dengan kapasitas dibawah 100.000 ton pertahun seperti Republik Fiji, Kaledonia Baru dan Malaysia. Untuk menjamin pasokan semen di wilayah Kepulauan Maluku dan Wilayah Papua serta daerah terpencil lainnya perlu dievaluasi kemungkinan pembangunan pabrik semen sekala kecil di daerah tersebut.

\section{ABSTRAT}

The Indonesian country has cement material such limestone, clay, quartz sand, and iron sand which is widely distributed in all big and small island in Indonesia. In Mollucas Archipelago and Papua region, cement supply is come from South Sulawesi until in those region some time lost cement in the market. Other country, like Fiji, New Caledonia, Malaysia etc was developed mini cement plant with capacity below 100.000 ton per anum. For garanting cement supply in those region is necessary to evaluating for develop the mini cement plant.

\section{Pendahuluan}

Penggunaan batu gamping dalam industri kimia termasuk semen telah berlangsung sejak zaman penggunaan mortar gamping dan semen alami mulai dikenal dalam peradaban umat manusia. Bahkan bangsa Jerman menyebutkannya bahwa batu gamping sebagai bahan baku dengan sejarah beragam (Kalkstein ein Rohstoff mit vielen Gesichtern). Pada zaman modern, peradaban manusia sangat tergantung pada semen dan hal ini dapat diamati dalam kehidupan sehari-hari, penggunaan semen sangat luas terutama dalam pembangunan sarana dan prasarana perhubungan, pemukiman, bendungan, terowongan, Hal ini disebabkan semen memiliki keunggulan antara lain mudah dibuat, mudah dipakai, murah, mudah diangkut dan kuat.

Semen (cement) adalah hasil industri dari paduan bahan baku : batu kapur/gamping sebagai bahan utama dan lempung / tanah liat atau bahan pengganti lainnya dengan hasil akhir berupa padatan berbentuk bubuk/bulk, tanpa memandang proses pembuatannya, yang mengeras atau membatu pada pencampuran dengan air. Semen digunakan sejak dibangunnya piramid oleh orang Mesir. Orang
Yunani dan Roma telah menggunakan tuf vulkanik yang dicampur dengan batu gamping sebagai semen. Pada tahun 1824, Joseph Aspdin dari Inggeris, medapatkan paten semen "portland" yang dibuat dengan mengkalsinasi batu gamping argilaseo. Pada awalnya, semen portland dibuat dari batu gamping argilaseo yakni batu gamping yang mengandung lempung yang dikenal sebagai batuan semen (cement rock) yang ditemukan di Inggeris. Amerika Serikat membangun pabrik semen portland di New Jersey dan daerah Lehigh di Pennsylvania. Jenis semen ini dapat menjadi keras secara cepat apabila dicampur dengan air. Dinamakan portland karena beton yang dibuat dengan semen ini sangat menyerupai batu bangunan yang terkenal dan ditemukan di pulau Portland, Inggris. Penamaan semen ini dimaksudkan untuk membedakan dengan semen pozolan, semen alumina, semen belerang, semen sorel (semen magnesium oksiklorid) dan semen lainnya. Semen portland didefinisikan sebagai prroduk yang didapatkan dari penggilingan halus klinker yang terdiri dari kalsium silikat hidrulik, dan mengandung satu atau dua bentuk kalsium silikat sebagai tambahan antar giling. 
Penggunaan semen pertama digunakan untuk membuat beton. Beton adalah batuan buatan yang terbuat hasil campuran antara semen, air, pasir, batangan besi, dan kerikil secara terkontrol dengan perbandingan tertentu dan teliti. Dari penemuan beton ini selanjutnya berkembang industri semen. Saat ini juga berkembang semen jenis Mansory yakni semen portland yang memiliki kelebihan lempung sebanyak 10\%. Sebelum tahun 1900, beton belum banyak digunakan karena proses pembuatan semen portland sangat mahal. Dengan ditemukannya berbagai mesin yang dapat menghemat tenaga manusia, semen sekarang sangat murah. Untuk melindungi konsumen, banyak negara yang mengatur komposisi kimia semen portland dalam peraturan standar nasional berbagai negara, termasuk Standar Nasional Indonesia.

Menurut George T. Austin (1996), pada tahun 1980, Amerika Serikat memiliki 142 pabrik semen portland dengan kapasitas produksi mencapai 63.800 .000 ton. 10 dari 142 pabrik menghasilkan sebanyak 30.624 .000 ton (48\%) dari produk semen di AS dan 20 pabrik menghasilkan 45.936.000 ton (72\%). Dengan demikian dapat disimpulkan bahwa di Amerika Serikat terdapat 122 pabrik yang menghasilkan semen sebanyak 28\% yakni 17.864 .000 ton. Bila dirata-ratakan diperoleh kapasitas rata-rata pabrik semen di AS dalam kelompok ini adalah 150.000 ton semen pertahun. Sedangkan pabrik dengan kapasitas antara 3,5-4,0 juta ton pertahun hanya 10 pabrik. Hal yang menarik, 45 dari 52 negara bagian Amerika Serikat memiliki pabrik semen. Sedangkan di Indonesia, pabrik semen terdapat di Aceh Besar (hancur akibat bencana tsunami 2004), Padang, Cibinong, Palimanan, Gresik, Pankep dan Tanah Toraja (5 provinsi).

Sejak abad ke-20, industri semen berkembang sangat pesat seluruh negara di dunia, dan menjadi kunci pengembangan industri dalam kerangka memenuhi kebutuhan pokok papan dari tiga kebutuhan pokok utama yakni sandang, papan dan pangan. Pada tahun 2007, dunia menghasilkan semen sebanyak 2,5 miliar ton, sedangkan pada tahun 1980hanya mencapai 850 juta ton atau naik hampir 3 kali lipat dalam waktu 25 tahun. Hampir seluruh negara di dunia memiliki semen termasuk Singapura (kapasitas produksi 3,5 juta ton per tahun), Hongkong (kapasitas produksi 2,5 juta ton per tahun). Negara yang tidak memiliki pabrik semen adalah Timor Leste. Negara utama penghasil semen dunia adalah RRC mencapai 1.100 juta ton, India 160 juta ton, AS 102 juta ton, Jepang 70 juta ton, Korea Selatan
62 juta ton, Thailand 50 juta ton dan Indonesia 42 juta ton, sedangkan pada tahun 1992 kapasitas produksi semen di Indonesia mencapai 22,4 juta ton. Selain itu banyak negara di Afrika yang mampu mwengembangkan pabrik semen dengan sekala menengah (300.000-700.000 ton. Bahkan terdapat beberapa negara yang mendirikan pabrik semen sekala kecil dengan kapasitas lebih rendah 300.000 ton pertahun. Beberapa negara yang mengembangkan pabrik semen kapasitas lebih kecil dari 100.000 ton pertahun seperti Fiji, Lebanon, Malawi, Kongo, Madagaskar, Kaledonia Baru, Suriname, Nigeria dan Uganda (lihat tabel 1).

Dari tabel 1, hal yang sangat menarik, terdapatnya beberapa negara bahkan sekitar kawasan Pasifik, berkembang pabrik semen dengan kapasitas dibawah 100.000 ton pertahun seperti yang dibangun di Fiji, Kaledonoa Baru, dan Malaysia. Di pinggir kota Kuching di Serawak Malaysia Timur juga terdapat pabrik semen sekala kecil. Berkembangnya pabrik semen sekala kecil ini disebabkan, negara tersebut memiliki bahan baku terbatas dan impor semen dari negara lain sangat mahal. Negara Importir harus membeli dengan harga lebih mahal dari harga pasaran internasional karena produksi semen tergantung pada permintaan domestik, menanggung ongkos angkutan dari pabrik dan biaya distribusi dalam negeri.

Sedangkan di Indonesia, berkembang pabrik semen dengan kapasitas diatas 1 (satu) juta ton, sebaliknya Wilayah Maluku dan wilayah Papua yang meliputi 4 provinsi hingga saat ini tidak memiliki pabrik semen. Wilayah tersebut selama ini, semen didatangkan dari Sulawesi Selatan. Harga juga murah yakni ditentukan oleh pemerintah berdasarkan jarak dengan pabrik. Permasalahan, konsumen di pedalaman Papua harus menanggung ongkos angkut sehingga harga semen sangat mahal.

\section{Perkembangan Industri Semen di Indonesia}

Kapasitas terpasang industri semen di Indonesia pada tahun 2005 telah mencapai 46 juta ton sedangkan pada tahun 1993 baru mencapai 22,4 juta ton. Penyelidikan dan Eksplorasi bahan baku semen telah dimulai sejak masa kolonial Belanda. Industri semen di Indonesia dimulai pada tahun 1913 dengan berdirinya pabrik semen milik maskapai Belanda (NV Ned. Ind. Portland Cement Maatchappij) dengan kapasitas 50.000 ton per tahun di Indarung Sumatera Barat. Pada tahun 
1957, pabrik ini diambil alih oleh pemerintah RI menjadi PT. Semen Indarung (dinasionalisasikan), dan selanjutnya pabrik ini berkembang pesat pada era 1970-1976. Pada tahun 1957, pabrik ini diperluas dengan pabrik Unit II berkapasitas 330.000 ton. Di Gresik Jawa Timur, berdiri pabrik semen kedua di dengan kapasitas 250.000 ton per tahun, dan selanjutnya pada tahun 1961 diperluas dengan pendirian pabrik semen unit II berkapasitas 125.000 ton.

Pada tahun 1968, didirikan pabrik semen Tonasa Kabupaten Pangkep (Provinsi Sulawesi Selatan) dengan menggunakan proses basah dengan kapasitas 110.000 ton pertahun dan merupakan pabrik pertama yang dibangun oleh pemerintah Republik Indonesia dengan menggunakan teknologi basah. Pada tahun 1980, didirikan unit II dengan kapasitas 510.000 ton pertahun dengan teknologi pengolahan kering. Pada tahun 1984, pabrik semen unit I dengan kapasitas 110.000 ton dihentikan operasinya karena tidak ekonomis.

Mulai tahun 1975, berdiri pabrik semen yang dibangun dengan modal asing seperti Semen Cibinong di Kabupaten Bogor yang didirikan oleh Gypsum Carrier Inc dan Bamerical International Finance, (USA) dengan kapasitas unit pertama sebesar 750.000 ton pertahun. Pembangunan pabrik ini diperlukan biaya 276 juta dolar AS dengan sumber dana sindikasi sebanyak 17 perbankan internasional yang dipimpin oleh Bank of America, Bank Exim (kini Bank Mandiri) dan Deutsche Bank. Selanjutnya berdiri industri semen dengan fasilitas PMA seperti Semen Nusantara (1974, kapasitas unit I sebesar 95.000 ton), dan Semen Andalas di Banda Aceh (kapasitas unit I sebesar 1 juta ton). Pada tahun 1984, berdiri pabrik semen milik PT Semen Kupang dengan kapasitas 120.000 ton pertahun di Kupang milik pemerintah dengan sumber dana dari Pemerintah Pusat, Pemerintah Provinsi NTT dan Bapindo (kini dilebur menjadi Bank Mandiri). Jadi berdasarkan perkembangannya, industri semen di Indonesia berdiri dari kapasitas kecil, termasuk yang didirikan oleh PMA.

Berdasarkan perkiraan pihak Departemen Perindustrian, pada tahun 2011 Indonesia akan menghadapi krisis semen akibat pertumbuhan kebutuhan semen dalam negeri mencapai 8\% sampai dengan $10 \%$ per tahun (Herry Rodiana Eddy, 2008). Berdasarkan Keputusan Menteri Perdagangan No. 132 Tahun 1993 Tentang Barang-barang yang diatur Tata Niaga, semen tidak termasuk kelompok tersebut. Dengan demikian impor semen bisa dilakukan secara bebas oleh pedagang dan pemerintah juga membebaskan cukai dan hanya dikenakan pajak penambahan nilai (PPn 10\%). Dengan kebijakan tersebut, pedagang tidak menarik untuk melakukan impor semen karena jumlahnya relatif kecil dan tidak menerus serta harga semen dalam negeri masih lebih rendah dari harga pasar internasional. Oleh karenanya perlu dievaluasi kembali tentang kemungkinan pendirian pabrik semen sekala kecil.

\section{Pabrik Semen Sekala Kecil}

Menurut beberapa penulis, pabrik semen sekala kecil (mini-cement plant) didefinisikan sebagai klinker tegak (vertical shaft kiln, lihat bagan) dengan kapasitas produksi antara 20 sampai dengan 200 ton semen per hari. Menurut Werner Gwosdz (1991), terdapat beberapa keuntungan dari klinker tegak antara lain :

a). Kapasitas pabrik semen sekala kecil dapat mengikuti dan menyesuaikan diri dengan pertumbuhan permintaan karena berdekatan dengan pasar seperti kawasan pertumbuhan, perkotaan dan pemukiman penduduk.

b). Dapat didirikan pada lokasi dengan kondisi endapan bahan baku kecil dan terbatas seperti batu gamping, marmer atau batuan karbonat lainnya. Di beberapa lokasi, sebaran endapan terbatas dan tidak dimungkinkan membangun pabrik semen sekala besar.

c). Pabrik semen sekala kecil dapat berkembang pada wilayah pemukiman, dapat membuka lapangan kerja baru dan terciptanya keseimbangan pengembangan wilayah secara regional.

d). Diperlukan investasi yang rendah dengan peralatan pabrik seperti mesin-mesin yang digunakan sederhana dan mudah dijalankan, dapat menghasilkan semen secara cepat dan mudah alih teknologi pada pekerja dengan pendidikan rendah serta mudah dijalankan prosedur operasional dalam proses produksi dan proses pemeliharaan pabrik.

Selain itu juga, diperoleh keuntungan ekonomi dalam pengembangan pabrik semen sekala kecil antara lain adalah :

a). Investasi modal awal per satuan unit produksi rendah dan hanya diperlukan 40 sampai dengan 50\% dari modal pendirian pabrik semen dengan klinker putar sekala 
menengah dan sekala besar. Ongkos pemeliharaan dan penggantian spare part rendah.

b). Ongkos energi per unit klinker juga rendah karena aliran panas dalam klinker sempurna yang disebabkan ukuran klinker kecil dan dapat digunakan batubara sebagai bahan bakar.

c). Kebutuhan media penggerusan (grinding) rendah karena sifat porositas klinker itu sendiri.

d) Rendahnya ongkos angkut dan biaya distribusi karena berdekatan dengan konsumen serta dimungkinkan pengiriman semen tanpa pembungkusan.

e). Pembangunannya cepat, krang lebih diperlukan waktu antara 12 sampai dengan 18 bulan untuk pabrik semen sekala kecil jenis klinker tegak. Sedangkan pembangunan pabrik semen sekala besar dengan klinker putar diperlukan waktu antara 48 sampai dengan 60 bulan.

f. Dapat bersaing dalam hal ongkos produksi setiap ton dengan pabrik semen sekala besar.

Klinker tegak (Vertical shaft kiln) berkembang di perusahaan semen di Eropah dengan ukuran tinggi antara 7 sampai dengan 9 meter dan berdiameter antara 2,40 sampai dengan 3,0 meter. Untuk jelasnya perhatikan gambar 1 . Klinker diberi umpan dengan butiran dan bongkahan campuran bahan baku semen (batu gamping, lempung dan bahan korektif lainnya) dan bahan bakat padat. Klinker tegal dapat berdaya guna dengan kapasitas bebera ton per hari dan maksimum 200 ton per hari (Spence, 1980). Sedangkan klinker putar, efisisensi minimal dengan kapasitas produksi 300 ton per hari bahkan dengan ongkos energi tinggi, efisiensi tercapai dengan kapasitas produksi 3000 sampai dengan 4000 ton perhari. Sedangkan ongkos pendirian pabrik dapat diperhatikan tabel 2.

\section{Bahan baku semen}

Semen dibuat dengan campuran kalsium, silica, alumina dan besi. Bahan ini merupakan campuran batu gamping dan lempung serta ditambang material lain seperti pasir besi dan gipsum. Untuk mendapatkan 1 ton semen, diperlukan bahan baku (perkiraan) sebagai berikut :

\section{$1,30-1,35$ ton batu gamping $0,30-0,35$ ton lempung}

\section{$0,02-0,06$ ton pasir kuarsa}

$0,01-0,02$ ton pasir besi

\section{0,04 gipsum.}

Perkiraan ini tidak mutlak dan sangat tergantung pada komposisi kimia bahan baku yang ditemukan. Bahan baku utama pendirian pabrik semen, minimal memiliki bahan baku batu gamping dan lempung. Bahan baku lainnya dapat didatangkan dari tempat lain. Disamping itu juga diperlukan air dalam proses pembuatan semen terutama yang menggunakan proses basah. Saat ini, proses basah, cenderung ditinggalkan. Pada proses kering diperlukan air untuk pendingin dan kebutuhan air bersih. Proses basah dilakukan dimana semua bahan baku dicampur dengan air, dihancurkan dan diuapkan kemudian dibakar dengan menggunakan bahan bakar minyak, bakar (bunker crude oil). Proses ini jarang digunakan karena masalah keterbatasan energi BBM. Sedangkan proses keringl, digunakan teknik penggilingan dan blending kemudian dibakar dengan bahan bakar batubara. Proses ini meliputi lima tahap pengelolaan yaitu : proses pengeringan dan penggilingan bahan baku di rotary dryer dan roller meal, proses pencampuran (homogenizing raw meal) untuk mendapatkan campuran yang homogen, proses pembakaran raw meal untuk menghasilkan terak (clinker: bahan setengah jadi yang dibutuhkan untuk pembuatan semen), proses pendinginan terak, dan proses penggilingan akhir di mana klinker dan gipsum digiling.

Kalsium dapat dipenuhi dari batu gamping, marmer dan batuan karbonat lainnya dengan komposisi $\mathrm{CaO}$ lebih dari $44 \%$ berat $(\mathrm{W})$, unsur MgO kurang dari 3,5\% W, unsur alkali lurang dari $0,6 \% \mathrm{~W}$, dan $\mathrm{P} 2 \mathrm{O} 5$ kurang dari $0,6 \% \mathrm{~W}$. India membangun pabrik semen dengan batu gamping yang mengandung $\mathrm{MgO}$ lebih tinggi dari $3,5 \% \mathrm{~W}$ yakni hampir mendekati $5 \% \mathrm{~W}$.

Sedangkan lempung, terdapat pabrik semen yang menggunakan tanah sawah sebagai lempung seperti yang dilakukan oleh Semen Tuban di jawa Timur dan pelapukan lateritik sebagai lempung dan bijih besi yang digunakan oleh Semen Kupang. Biasanya dalam pembuatan semen digunakan lempung dan batu lumpur yang mengandung kaolin, illit dan smektit. Gipsum digunakan untuk mengatur waktu pengerasan semen setelah dicampur dengan air. Sedangkan untuk membangun pabrik semen sekala kecil juga diperlukan bahan baku yang diperlukan sama dengan bahan baku semen konvensional. 
Dari tabel 3 menunjukkan bahwa, pabrik semen sekala kecil tidak memerlukan bahan baku dengan cadangan besar. Untuk kapasitas 200 ton perhari, diperlukan wilayah yang memiliki cadangan batugamping sebesar 1,8 sampai dengan 2,25 juta ton untuk pabrik beroperasi selama 20-25 tahun. Sedangkan lempung diperlukan sebanyak $25 \%$ dari kebutuhan batu gamping. Lempung kemungkinan lebih mudah ditemukan. Bila diperhatikan bahan baku, tidak menjadi masalah membangun pabrik semen sekala kecil, sekala menengah maupun sekala besar di Kepulauan Maluku, Wilayah Papua maupun wilayah terpencil lainnya. Untuk membangun pabrik semen di Kepulauan Maluku dan Wilayah Papua, bahan baku batu gamping dan lempung tidak menjadi masalah karena keterdapatannya melimpah (lihat tabel 4).

Penyelidikan dan eksplorasi batu gamping di wilayah Kepulauan Maluku dan Papua, umumnya berdekatan dengan pusat pemukiman dan daerah pertumbuhan seperti Jayapura, manokwari, Sorong, Ternate dan Halmahera. Sebuah Kontrak karya Pertambangan Umum PT. Pacifik Nikklel Indonesia, juga pernah menyelidiki bahan baku semen dan bahan bangunan lainnya di Halmahera dan kawasan Kepala Burung untuk kepentingan kontruksi peleburan dan penbangunan infrastruktur peleburan bijih nikel di pulau Gag. Rencana tersebut tidak terujut karena pabrik peleburan nikel di pulau Gag gagal akibat invetasi terlalu tinggi dan tidak diperoleh dana sindikasi.

Umunya batu gamping di daerah tersebut dapat digunakan untuk bahan baku semen, dengan komposisi $\mathrm{CaO}$ antara $51 \%$ sampai dengan $55 \%$ dan $\mathrm{MgO}$ lebih kecil dari 3\%. Di kawasan ini juga terdapat batu gamping di Abepura dengan sumber daya terukur 50,3 juta ton namun mengandung dolomit. Jika dibandingkan dengan skenario kebutuhan pabrik semen sekala kecil, seluruh lokasi keterdapatan batu gamping yang telah ditemukan dapat digunakan untuk kepentingan industri semen. Sedangkan lokasi keterdapatan lempung, lokasi dengan staus sumber daya terukur terdapat di Abepura dengan sumber daya hipotetik 30.000 .000 ton dan sumber daya terukur sebesar 319.000 ton. Hasil penyelidikan tersebut diatas merupakan penyelidikan tahap awal. Untuk mendirikan pabrik semen berkapasitas besar, cukup memilih 1 lokasi dari daerah keterdapatan batu gamping tersebut diatas dan tidak perlu mencari areal baru. Areal baru batu gamping di Papua terhampar luas. Eksplorasi bahan baku semen juga mudah dan murah. Semen Kupang dengan 2 titik bor telah cukup untuk membuat kajian kelayakan tambang dan kelayakan pabrikan/manufaktur.

Di daerah Papua, sebuah BUMN pada tahun 1990an telah melakukan kajian dan eksplorasi tinjau kemungkinan pembangunan pabrik semen sekala besar diatas 1,5 juta ton. Perusahaan ini tertarik untuk daerah Abepura di Jayapura. Didaerah ini terdapat bahan baku semen berupa batu gamping dengan sumber daya terukur 142 juta ton, tereka 149,35 juta ton di Gunung Mer dan beberapa lokasi hipotetik yang jumlahnya mencapai 200 juta ton. Berhubung konsumsi semen di wilayah Papua pada tahun 1992, hanya 129.000 ton maka pendirian pabrik tersebut tak pernah terujut. Apalagi terdapat kecenderungan bahwa pabrik semen yang ekonomis berkapasitas diatas 1,5 juta ton. Saat ini, kebutuhan semen di Maluku dan Papua sekitar 500.000 ton. Seharusnya bisa didirikan pabrik semen sekala menengah namun, kebutuhan semen di Maluku dan Papua telah tersedia dan dikuasai oleh semen yang berasal dari Tonasa dan Bosowa Sulawesi Selatan. Kebutuhan semen di Papua sebagian besar diperlukan oleh perkotaan di tepi pantai seperti Jayapura, Biak, Manokwari, Nabire, Sorong, Fakfak, Timika dan Merauke dapat diatasi dengan semen dari Sulawesi Selatan dengan harga yang sama dengan harga semen di wilayah Indonesia lainnya. Yang menjadi masalah, kebutuhan semen di daerah pedalaman Papua seperti kabupaten Jayawijaya, Wamena, Paniai, Yohukuma, Oksibil harus melalui angkutan udara. Dengan selesainya jalan poros Nabire-Paniai, kebutuhan semen di paniai dapat teratasi. Seangkan di Kepulauan maluku juga dimungkinkan untuk dijadilah daerah pilihan lain yang prospektif. Permasalahannya, kota-kota di kepulauan Maluku, terletak dipantai yang dapat dipasok dari Sulawesi dan Kupang. Sedangkan transportasi darat di halmahera relatif lebih baik.

Walaupun demikian, perlu dikaji ulang kemungkinan pendirian pabrik semen di Papua atau Maluku dengan diawali pembangunan pabrik semen sekala kecil terlebih dahulu seperti halnya dengan pendirian pabrik semen di Indarung, Gresik dan Tonasa yang pada awalnya mendirikan barik dengan kapasitas tertinggi di Tonasa dengan kapasitas 110.000 ton. Dan bila diamatri di sekitar tetangga papua juga terdapat pabrik semen dengan kapasitas 100.000 ton pertahun yang didirikan di Vanuatu Republik Fiji. Bahkan Suriname mampu mendirikan pabrik semen dengan kapasitas 35.000 ton. Bila perlu industri semen ala 
Suriname didirikan di bagian Pegunungan Papua dalam bentuk kerja sama antar kabupaten, minimal 3 kabupaten. Daerah Kokas di Fakfak, yang merupakan bagian Kerja Sama Pembangunan Wilayah Teluk Bintuni yang mencakup 5 kabupaten, sudah semestinya memikirkan kemungkinan pembangunan pabrik semen sekala kecil. Demikian juga halnya dengan kawasan NabireBiak Nunfor - Yapen Waropen atau Kawasan Oksibil- Boven Digul-Merauke perlu diwacakan kemungkinan kerja sama pembangunan pabrik semen sekala kecil. Saat ini di wilayah Papua terdapat ijin investasi pabrik semen dengan kapasitas 100.000 ton di Irian Jaya Barat milik PT Semail Bangun Harjo (Herry Rodiana Eddy, Buletin Sumber Daya Geologi No. 2 tahun 2008). Untuk menbangun pabrik semen dengan kapasitas 120.000 ton diperlukan dana sekitar 19 juta dolar AS sedangkan untuk membangun pabrik semen berkapasitas 1.5 - 2,3 juta ton pertahun diperlukan dana sebesar 150 dolar AS per ton. Cadangan batu gamping yang diperlukan hanya untuk pabrik semen sekala kecil 3,6 juta ton dengan umur pabrik 20 tahun atau 4,5 juta ton untuk umur pabrik 25 tahun dengan kapasitas 120.000 ton per tahun.

Bila diamati perkembangan industri semen di Indonesia, permasalahan bukan di bahan baku tetapi pada modal investasi dan permasalahan keuangan setelah pabrik berdiri dan beroperasi. Pabik semen dengan fasilitas PMA dan sindikasi perbankan umumnya sulit berkembang akibat krisis keuangan internal dan perselisihan antar pemilik saham. Akibatnya pabrik tersebut diperjual belikan.

\section{Kesimpulan}

Bila diamati perkenbangan industri semen secara mengglobal, hapir semua negara di dunia ini memiliki pabrik semen bahkan berkembang pabrik semen sekala menengah dan kecil. Sebagian besar pabrik semen di Amerika Serikat berukuran kecil yakni dengan kapasitas 150.000 ton. Di sekitar Pasifik juga berkembang pabrik semen dengan sekala kecil. Wilayah Indonesia memiliki bahan baku semen tersebar di seluruh kepulauan, oleh karenanya kajian kemungkinan pendirian pabrik semen sekala kecil di daerah Maluku, Papua dan daerah terpencil lainnya diperlukan.

\section{Ucapan Terima kasih}

Penulis mengucapkan terima kasih kepada rekan-rekan, khususnya sdr Drs. Nandang Sumarna yang mendorong agar naskah kemungkinan pendirian pabrik semen sekala kecil untuk dimuat dalam buketin Sumber Daya Geologi.

\section{ACUAN}

Austin George T, dan Jasji E, 1996, Industri Proses Kimia, Penerbit Erlangga.

Capricorn Indonesia Consult Inc PT, 1993, Studi tentang Prospek Industri dan Pemasaran Semen di Indonesia 1993, 91 halaman.

Gwosdz Werner, Kreimeyer R, 1991, The Possible Establishment of A Cement Industry in Botswana Using Small Scale Cement Plant Technology, Natural Resources and development Vol 34, Institute for Scientific Co-opertion, Tubingen.

Madiadipoera, T, 2006, Bahan Galian Industri di Indonesia, Publikasi Khusus Pusat Sumber Daya Geologi No. 36 ISSN 0216-0765, 198 halaman.

Rodiana HE, 2008, Potensi Bahan Baku Semen di Kawasan Timur Indonesia, Buletin Sumber Daya Geologi Vol 3 Nomor 22008. 


\section{MAKALAH ILMIAH}

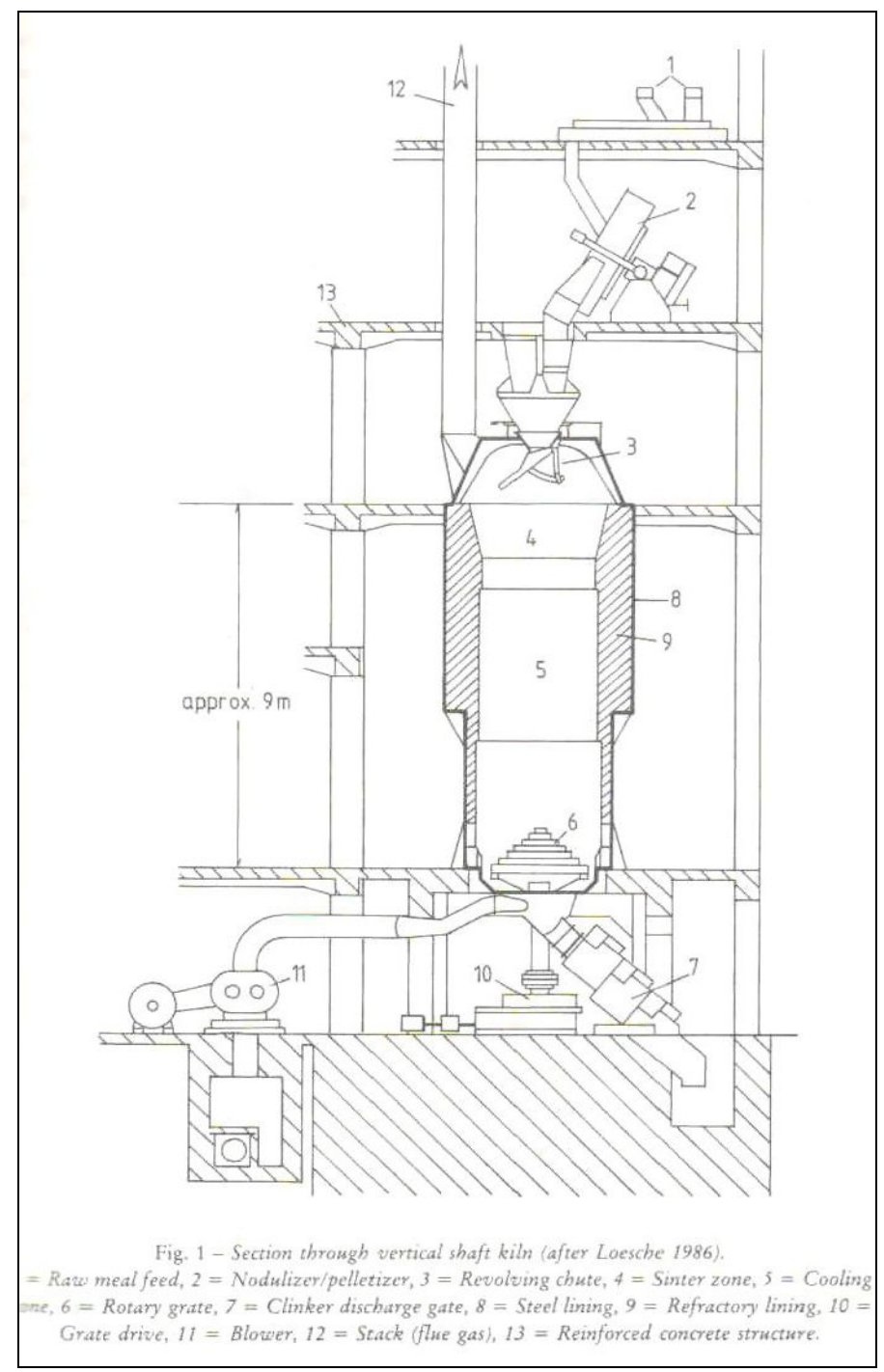

Bagan, Kilen Vertkal Pabrik semen Sekala Kecil.

Tabel 1. Kapasitas Pabrik Semen Sekala Menengah dan Kecil Dunia (Ton)

\begin{tabular}{|l|l|l|l|l|l|}
\hline No. & \multicolumn{1}{|c|}{ Negara } & \multicolumn{1}{c|}{ Kapasitas } & No. & \multicolumn{1}{c|}{ Negara } & \multicolumn{1}{c|}{ Kapasitas } \\
\hline 1. & Kostarika & 575.000 & 17. & Mali & 220.000 \\
\hline 2. & Myanmar & 525.000 & 18. & Monggolia & 220.000 \\
\hline 3. & Mozambik & 500.000 & 19. & Guadelup & 220.000 \\
\hline 4. & Zaire & 500.000 & 20. & Gabon & 150.000 \\
\hline 5. & Tanzania & 450.000 & 21. & Islandia & 120.000 \\
\hline 6. & Honduras & 440.000 & 22. & Nikaragua & 110.000 \\
\hline 7. & Togo & 400.000 & 23. & Fiji & 100.000 \\
\hline 8. & Trinidad \& Tobago & 400.000 & 24. & Lebanon & 100.000 \\
\hline 9. & Uruguai & 400.000 & 25. & Malawi & 75.000 \\
\hline 10. & Zambia & 400.000 & 26. & Kongo & 65.000 \\
\hline 11. & Panama & 385.000 & 27. & Kaledonia Baru & 60.000 \\
\hline 12. & Luxemburg & 340.000 & 28. & Suriname & 55.000 \\
\hline 13. & Qatar & 330.000 & 29. & Nigeria & 44.000 \\
\hline 14. & Ghana & 300.000 & 30. & Madagaskar & 40.000 \\
\hline 15. & Pantai Gading & 275.000 & 31. & Malaysia & 38.000 \\
\hline 16. & Haiti & 220.000 & 32. & Uganda & 20.000 \\
\hline
\end{tabular}


Tabel 2. Ongkos Peralatan untuk Klinker Vertikal dan Klinker Putar

\begin{tabular}{|c|c|c|}
\hline \multirow{2}{*}{$\begin{array}{c}\text { Kapasitas } \\
\text { Ton/Tahun }\end{array}$} & \multicolumn{2}{|c|}{ Total Investasi dalam US\$/ton } \\
\cline { 2 - 3 } & Klinker Tegak & Klinker putar \\
\hline 60.000 & 220 & - \\
\hline 120.000 & 165 & 215 \\
\hline 240.000 & 140 & 170 \\
\hline
\end{tabular}

Tabel 3. Kebutuhan Bahan Baku Semen Sekala Kecil (Portland dan Pusolan)

\begin{tabular}{|c|c|c|c|c|c|}
\hline & \multicolumn{4}{|c|}{ Kapasitas Klinker Harian (Ton/hari) } \\
\hline & & 50 & 100 & 150 & 200 \\
\hline \multirow{2}{*}{$\begin{array}{l}\text { Produksi } \\
\text { Tahunan }\end{array}$} & Pusolan Semen & 20.500 ton & 41.000 ton & 61.500 ton & 82.500 ton \\
\hline & Portland Semen & 15.000 ton & 30.000 ton & 45.000 ton & 60.000 ton \\
\hline \multirow{4}{*}{$\begin{array}{l}\text { Kebutuhan } \\
\text { Bahan Baku } \\
\text { (ton) }\end{array}$} & Batu Gamping & 22.500 & 45.000 & 67.500 & 90.000 \\
\hline & $\begin{array}{l}\text { Lempung, } \text { batu } \\
\text { lumpur, serpih, dan } \\
\text { bahan korektif }\end{array}$ & \multicolumn{4}{|c|}{$\begin{array}{l}\text { Biasanya } 25 \% \text { dari batu gamping yang disesuaikar } \\
\text { dengan komposisi dan rasio silika. }\end{array}$} \\
\hline & Gipsum & 750 & 1.500 & 2.250 & 3.000 \\
\hline & Material Pusolan & 4.725 & 9.450 & 14.175 & 18.900 \\
\hline \multirow{2}{*}{$\begin{array}{l}\text { Cadangan } \\
\text { batu gamping } \\
\text { (ton) }\end{array}$} & 20 tahun & 450.000 & 900.000 & 1.350 .000 & 1.800 .000 \\
\hline & 25 tahun & 562.500 ton & 1.125 .000 & 1.687 .000 & 2.250 .000 \\
\hline \multicolumn{6}{|c|}{$\begin{array}{l}\text { Catatan: } \\
\text { Operasi klinker } 300 \text { hari per tahun, } \\
\text { Rasio batugamping/klinker }=1,5 \\
\text { Kebutuhan material puzzolan } 30 \% \text {. }\end{array}$} \\
\hline
\end{tabular}

Tabel 4. Lokasi Keterdapatan Batugamping di Kepulauan Maluku dan Wilayah Papua

\begin{tabular}{|c|c|c|c|c|}
\hline \multirow{2}{*}{ Lokasi } & \multicolumn{4}{|c|}{ Sumber Daya (Ton) } \\
\hline & Hipotetik & Tereka & Terunjuk & Terukur \\
\hline $\begin{array}{l}\text { Gotowagi, Kabupaten Halmahera } \\
\text { Tengah }\end{array}$ & 63.608 .000 & & & \\
\hline Mumar, Kabupaten Halmahera Tengah & & & 34.290 .000 & \\
\hline Desa Fayaul, Kab. Halmahera Tengah & 3.103 .110 .000 & & & \\
\hline Weda, Kab Halmahera Tengah & 2.700 .000 .000 & & & \\
\hline Pulau Mandioli Halmahera Selatan & 1.350 .000 .000 & & & \\
\hline $\begin{array}{l}\text { Pulaua Moraotai. Kab. Halmahera } \\
\text { Utara }\end{array}$ & 1.620 .000 .000 & & & \\
\hline Abepantai Jayapura & & & & 14.124 .000 \\
\hline Abepantai Jayapura & & & & 82.716 .000 \\
\hline Abepantai Jayapura & & & & 50.302 .000 \\
\hline Abe Pantai Blok F, Kab. Jayapura & 18.000 .000 & & & \\
\hline Abe Pantai Blok G, Kab. Jayapura & 83.000 .000 & & & \\
\hline Kotaraja, Abepura Kab. Jayapura & 5.000 .000 & & & \\
\hline Padangbulan Blok B Kab. Jayapura & 18.000 .000 & & & \\
\hline Pandang Bulan Blok C Kab. Jayapura & 20.000 .000 & & & \\
\hline Pim Jetti, Abepura Kab. Jayapura & 41.000 .000 & & & \\
\hline Gunung Mer Kabupaten Jayapura & & 149.359 .000 & & \\
\hline $\begin{array}{l}\text { Bukit Tuwanwowoi-Maroni Kab. } \\
\text { Manokwari }\end{array}$ & & 1.350 .000 .000 & & \\
\hline Bukit Miabator Kab. Sorong Kota & 5.000 .000 & & & \\
\hline Klademak Kab. Sorong Kota & 8.000 .000 & & & \\
\hline Skendi Kabupaten Sorong Selatan & 270.000 .000 & & & \\
\hline Kokas, Kabupaten Fakfak & 92.000 .000 & & & \\
\hline
\end{tabular}

